\title{
Soil water stress ranges: water use efficiency and Chinese cabbage production in protected cultivation
}

\author{
Dalva Paulus' ${ }^{1 \mathbb{D}}$; Ivan Carlos Zorzzi ${ }^{2} \mathbb{D}$; Fabiana Rankrape ${ }^{1} \mathbb{D}$
}

${ }^{1}$ Universidade Tecnologica Federal do Paraná (UTFPR), Dois Vizinhos-PR, Brasil. dalvapaulus@utfpr.edu.br (corresponding author); ${ }^{2}$ Universidade Tecnologica Federal do Paraná (UFTPR), Pato Branco-PR, Brasil; ivanzorzzi@gmail.com; fabianarankrape@gmail.com

\begin{abstract}
Water deficit or water excess can affect development and yield of vegetables. The objective of this study was to evaluate the effect of different soil water stress ranges for Chinese cabbage (Brassica pekinensis) in a protected cultivation. The researches were carried out at the Olericulture Sector of Universidade Federal Tecnologica do Paraná between April and July, 2015 and January and April, 2016. Two Chinese cabbage cultivars were analyzed (Eikoo and Kinjitsu) with four soil water stress range (13-17, 23-27, 33-37 and 43-47 kPa) moments of irrigation indicative parameters. The trial design was completely randomized, with four replications, in a factorial scheme. For head fresh mass, a soil stress range of 13-17 $\mathrm{kPa}$ resulted in higher yield (527.2 g/plant), in the first research. In the second one, 'Eikoo' showed higher productivity in the stress range $13-17 \mathrm{kPa}$ $\left(70.7 \mathrm{tha}^{-1}\right)$. About water use efficiency, higher values were obtained, $42.1 \mathrm{~kg} \mathrm{~m}^{-3}$ in the first research and $47.3 \mathrm{~kg} \mathrm{~m}^{-3}$ in the second one with Kinjitsu and Eikoo cultivars, respectively, in the stress range 13-17 kPa. 'Eikoo' had a higher productivity than 'Kinjitsu' in the second research (summer), but in the first one (autumn-winter) these differences were not expressive. The use of stress ranges as indicative of irrigation return time between $13-17 \mathrm{kPa}$ is suitable for Chinese cabbage crop.
\end{abstract}

Keywords: Brassica pekinensis, tensiometry, irrigation management, water deficit.

\section{RESUMO}

Faixas de tensão de água no solo: eficiência do uso da água e produção de couve chinesa em cultivo protegido

O déficit hídrico ou excesso de água pode afetar o desenvolvimento e produção das hortaliças. Objetivou-se avaliar o efeito de diferentes faixas de tensão de água no solo para a cultura da couve chinesa (Brassica pekinensis), em ambiente protegido. Os experimentos foram conduzidos no Setor de Olericultura, da Universidade Tecnológica Federal do Paraná entre abril e julho de 2015 e janeiro e abril de 2016. Foram estudadas duas cultivares de couve chinesa (Eikoo e Kinjitsu) e quatro faixas de tensão de água no solo (13-17, 23-27, 33-37 e 43-47 kPa), sendo parâmetros indicativos do momento de irrigar. $\mathrm{O}$ delineamento experimental utilizado foi inteiramente casualizado, com quatro repetições, em esquema fatorial. Para massa fresca da cabeça, a faixa de tensão do solo de 13-17 kPa resultou em maior produção $(527,2 \mathrm{~g} /$ planta $)$, no primeiro experimento. No segundo, 'Eikoo' apresentou maior produtividade na faixa de tensão 13-17 $\mathrm{kPa}\left(70,7 \mathrm{t} \mathrm{ha}^{-1}\right)$. Quanto à eficiência no uso da água, foram obtidos maiores valores, da ordem de $42,1 \mathrm{~kg} \mathrm{~m}^{-3}$ água no primeiro e $47,3 \mathrm{~kg} \mathrm{~m}^{-3}$ água no segundo experimento, para as cultivares Kinjitsu e Eikoo, respectivamente, na faixa de tensão 13-17 kPa. 'Eikoo' teve maior produtividade do que a 'Kinjitsu' no segundo experimento (verão), porém no primeiro experimento (outono-inverno) essas diferenças não foram expressivas. A utilização de faixas de tensão como indicativo do momento de retorno à irrigação entre $13-17 \mathrm{kPa}$ é adequada para a cultura da couve chinesa.

Palavras-chave: Brassica pekinensis, tensiometria, manejo da irrigação, déficit hídrico.

Received on August 9, 2018; accepted on April 15, 2019

$\mathrm{C}$ hinese cabbage (Brassica pekinensis) is considered the world's most important vegetable from Brassicaceae family when it comes to global consume, because it is a key element for diets in many Asian countries. Due to its wide acceptance and high nutritional value, as a source of vitamin C, minerals such as sodium, potassium, magnesium and calcium, there is a constant request for this vegetable (Laczi et al., 2016).
Understanding soil moisture is of underlying importance, as it indicates its water status. In irrigation, this should be determined and will serve as a parameter for the amount of water to be applied by the irrigation system. There are several methods for determining soil moisture, which differ mainly by measurement means, measurement site, installation, cost, response time and ease of field operation (Mantovani et al., 2009).

One of the most commonly used methods for indirect determination of soil moisture is the tensiometry, which uses sensors called tensiometers (Bernardo et al., 2006). Thompson et al. (2002) recommend, for broccoli and cauliflower, species of Brassicaceae, tensions between 10 and $12 \mathrm{kPa}$. Marouelli (2008) recommends the use of tensiometers in vegetable crops and leafy vegetables in general, and to keep tension between $10-20 \mathrm{kPa}$, seeking the lowest value for critical moments during 
its development.

Generally, vegetables show an underdeveloped root system, high water content in their constitution and a short cycle, so the occurrence of water deficit can severely compromise the farming (Marouelli, 2008). Thus, the great majority of vegetable crops in Brazil is conducted with irrigation, but an inadequate management can compromise the profitability and sustainability of production by excessive or poor water application (Beshir, 2017).

Having this in mind, the relevance of studies on hydric relations between crop, soil, environment and the minimum amount required for production maximization can be noted. There is a shortage of studies on irrigation management in Chinese cabbage. Therefore, the objective of this study was to evaluate the effect of different soil water stress ranges for Chinese cabbage in a protected environment.

\section{MATERIAL AND METHODS}

The research was carried out at Olericulture Sector of Universidade Federal Tecnologica do Paraná, Campus Dois Vizinhos $\left(25^{\circ} 42^{\prime} \mathrm{S}, 53^{\circ} 06^{\prime} \mathrm{W}\right.$, altitude $520 \mathrm{~m}$ ). Two researches were carried out, one from April to July 2015 and another from January to April 2016. The researches were conducted in a protected environment, arched model, covered with clear polyethylene, 150 $\mu$ thickness. The region climate is Cfa, according to Köppen classification (Alvares et al., 2013).

The trial design was completely randomized in a $2 \times 4$ factorial scheme, two cultivars (Eikoo and Kinjitsu) and four soil water stress ranges (13-17, 23-27, 33-37 and 43-47 kPa), with four repetitions. In each $18 \mathrm{~L}$ vase, a plant was managed, being considered an experimental unit, spaced $30 \mathrm{~cm}$ between plants and $60 \mathrm{~cm}$ between rows.

The soil used to fill the vases is classified as Dystroferric Red Latosol (Embrapa, 2018), taken from a 0-20 $\mathrm{cm}$ layer, dried, unstuck and sieved in a $3 \mathrm{~mm}$ mesh. These were the chemical characteristics of the soil: $5.8 \mathrm{pH}\left(\mathrm{CaCl}_{2}\right) ; 1.88 \%$ organic matter;
$11.78 \mathrm{P}\left(\mathrm{mg} \mathrm{dm}^{-3}\right) ; 76.32 \% \mathrm{~V} ; \mathrm{K}$, $\mathrm{Ca}, \mathrm{Mg}, \mathrm{Al}, \mathrm{H}+\mathrm{Al}, \mathrm{SB}\left(\mathrm{cmol}_{\mathrm{c}} \mathrm{dm}^{-3}\right)$ of $0.45 ; 6.10 ; 3.70 ; 0.00 ; 3.18$ and 10.25 , respectively. The soil was characterized as very clayey with $78.3 ; 16.7$ and $5.0 \%$ clay, silt and sand, respectively. Its microporosity, macroporosity and total porosity were respectively 0.42 ; 0.31 and $0.73 \%$; particle density $3.52 \mathrm{~g}$ $\mathrm{cm}^{-3}$; soil density $0.95 \mathrm{~g} \mathrm{~cm}^{-3}$. Soil water retention curve was determined in the Physics and Soil Water Laboratory of the Universidade de Passo Fundo, from undisturbed samples, collected at 0.10 $\mathrm{m}$ depth, with six repetitions (Figure 1). To determine the volumetric humidity of the low stress points ( 6 and $10 \mathrm{kPa}$ ) porous plate funnels were used; for 100 and $300 \mathrm{kPa}$ stress the Richards chamber and pedotransfer functions (Michelon $e t$ $a l ., 2010)$ were used, to determine the humidity at $1500 \mathrm{kPa}$. The relationship between stress and volumetric moisture was adjusted using the model proposed by Van Genuchten (1980), described in equation (1):

$$
\theta=\theta_{r}+\left(\frac{\theta_{s}-\theta_{r}}{\left[1+(\alpha|\Psi \mathrm{m}|)^{n}\right]^{m}}\right)
$$

Where $\theta=$ volume-based soil moisture $\left(\mathrm{m}^{3} / \mathrm{m}^{3}\right) ; \Psi \mathrm{m}=$ soil matrix potential $(\mathrm{kPa}) ; \theta_{\mathrm{r}}=$ residual volumetric moisture $\left(\mathrm{m}^{3} / \mathrm{m}^{3}\right) ; \theta_{s}=$ volumetric humidity at saturation $\left(\mathrm{m}^{3} / \mathrm{m}^{3}\right) ; \mathrm{m}, \mathrm{n}$ and $\alpha=$ model parameters.

The $m$ was obtained by equation (2) (Mualem, 1976):

$$
m=1-\left(\frac{1}{n}\right)
$$

In order to adjust the model, the RETC software was used (Van Genuchten et al., 1991). The values of the adjustment parameters were depth $=0.10 \mathrm{~m}$; residual volumetric moisture $\left(\mathrm{m}^{3} / \mathrm{m}^{3}\right)=0.078$; volumetric humidity at saturation $\left(\mathrm{m}^{3} / \mathrm{m}^{3}\right)=0.43 ; \mathrm{m}=0.359 ; \mathrm{n}=$ $1.56 ; \alpha=0.036$ and $\mathrm{R}^{2}=0.95$.

Seedlings were produced in a tray of expanded polystyrene with 128 cells, filled with commercial substrate Tecnomax ${ }^{\circledR}$. Vases were filled with soil and plantlets were transplanted with four to six leaves (Segovia et al., 2000), 17 days after sowing date, in both researches. In the 2015 research, transplant was performed on May 6, 2015 and harvest on July 15, 88 days after planting date (DAS), using as indication of harvest point the sturdy head (Segovia et al., 2000). In the second research, transplant was performed on February 1, 2016 and harvest on April 10 (87 DAS), done in advance due to diseases incidence.

Up to the tenth day after transplant, irrigation was homogeneous, to guarantee the glue. Afterwards, started the discrimination of cultivations. Irrigation management was performed based on soil matrix potential, determined by tensiometers. The irrigation liquid level was applied manually using a graduated cylinder, aiming to evenly distribute the water all over the vase. A tensiometer was installed at $10 \mathrm{~cm}$ depth per experimental unit, according to procedures indicated by Marouelli (2008). Stress readings were performed daily at the end of afternoon, using a digital tensiometer. When the mean stress reached the cultivation stress range, irrigation was performed until reaching the field capacity (CC). For the soil water stress ranges $(\mathrm{kPa}) 13$ $17 ; 23-27 ; 33-37$ and $43-47$, at the time of irrigation, the irrigation levels per application (L) were $0.22 ; 0.65 ; 1.02$ and 1.32 , respectively. Soil moisture corresponding to the observed/measured stress was determined by means of the water retention curve (Equation 2), considering the depth of root system $(100 \mathrm{~mm})$, vase area $\left(0.07 \mathrm{~m}^{2}\right)$ and mean value of the stress range humidity $\left(\theta_{\text {atual }}\right)$. Thus, the replacement volume was calculated (LLI) to reach the CC $\left(0.397 \mathrm{~m}^{3} \mathrm{~m}^{-3}\right)$, according to equation (3) (Mantovani et al., 2009).

$$
\mathrm{LLI}=\left(\theta_{c c}-\theta_{\text {atual }}\right) \cdot Z \cdot P A M
$$

Where LLI= irrigation liquid sheet $(\mathrm{mm}) ; \theta_{c c}=$ field humidity capacity $\left(\mathrm{m}^{3} /\right.$ $\left.\mathrm{m}^{3}\right) ; \theta_{\text {current }}=$ current humidity $\left(\mathrm{m}^{3} / \mathrm{m}^{3}\right)$; $\mathrm{Z}=$ root system depth $(\mathrm{mm}) ; \mathrm{PAM}=$ vase area $\left(\mathrm{m}^{2}\right)$.

The mean temperature provided by climatic data, relative humidity and radiation were obtained from the UTFPR meteorological station (16 UTC) at Campus Dois Vizinhos, located nearby the experimental unit. Potential evapotranspiration was estimated by the Penman-Monteith method (Allen et al., 1998).

Cultural practices, pest and disease 
control were carried out according to the recommendations of Segovia et al. (2000). Fertilization was calculated based on soil chemical characteristics laboratory report and on recommendation proposed by Segovia et al. (2000). The urea fertilization was divided into three $40 \mathrm{~kg} \mathrm{ha}{ }^{-1}$ applications, in the planting, 15 and 30 days after the transplant; while phosphorus and potassium were applied in $100 \mathrm{~kg} \mathrm{ha}^{-1}$ doses of $\mathrm{P}_{2} \mathrm{O}_{5}$ and $40 \mathrm{~kg} \mathrm{ha}^{-1}$ of $\mathrm{K}_{2} \mathrm{O}$, in one single application, when preparing the soil in the vases. Same fertilization was used in both researches.

During harvest, the head circumference was measured with a tape measure, with results expressed in $\mathrm{cm}$. To evaluate the compactness, grades from 0 to 5 were assigned, with 0 for plants with total head absence; 1 for plants with head without a defined core; 2 for plants with outside core head and loose peripheral leaves; 3 for plants with defined core head and leaves with inceptive compaction in the periphery; 4 for plants with defined core head and compact peripheral leaves, but with allowed visual individualization; and 5 for head with compact core and without visual individualization of the peripheral leaves (Souza et al., 2013).
To evaluate fresh mass, the aerial part was separated from the roots and weighed in a precision digital scale. Then, samples were taken to the drying oven at $65^{\circ} \mathrm{C}$ until constant mass.

Based on the considered spacing, population per hectare was estimated and multiplied by fresh mass of the head, estimating total productivity. Water use efficiency was calculated according to the productivity (dry mass of the head) and to the amount of water consumed by the crop in each cultivation during the cycle (Doorenbos \& Kassan, 1994).

Otained data were submitted to analysis of variance ( $\mathrm{F}$ test) and the cultivation effects obtained by means of Scott-Knott's test $(\mathrm{p}<0.05)$. Statistical analyzes were performed using GENES statistical software (Cruz, 2006).

\section{RESULTS AND DISCUSSION}

Mean temperature during the period of the research was $16.5^{\circ} \mathrm{C}$ in the first research and $21.8^{\circ} \mathrm{C}$ in the second one. This difference is attributed to the period when the researches were performed. The first research was carried out in autumn-winter period and the second one in summer-autumn period. Temperature conditions were suitable for the crop, considering that the majority of Chinese cabbage cultivars, including those used in this research, are adapted to temperatures between 15 and $25^{\circ} \mathrm{C}$ (Brasil, 2010).

There was no significant interaction between cultivars and soil water stress ranges for all analyzed traits in the first research. In the second one, there was a significant interaction, only for fresh and head dry mass, productivity and root dry mass.

Cultivars Eikoo and Kinjitsu did not differ significantly in the first research. However, in the second one, from 'Eikoo' a greater head fresh mass was obtained comparing to the 'Kinjitsu' (Table 1). Productivity was similar to head fresh mass, in which cultivar Eikoo produced $57.2 \mathrm{t} \mathrm{ha}^{-1}$, while 'Kinjitsu' produced $30.2 \mathrm{t} \mathrm{ha}^{-1}$. This response is conditioned to the cultivar characteristics, and 'Eikoo' can produce heads weighing $2.5-3.5 \mathrm{~kg}$ on average (Horticeres, 2015), while 'Kinjitsu' has a $2.2 \mathrm{~kg}$ mean head mass (Topseed, 2015). Based on this result, it can be suggested that the two cultivars can be conducted in the autumn-winter period, but 'Eikoo' can also be cultivated during summer period.

Table 1. Head fresh mass (HFM) and productivity of the Chinese cabbage submitted to different ranges of soil water stress in two crops. Dois Vizinhos, UTFPR, 2016.

\begin{tabular}{|c|c|c|c|c|c|c|}
\hline \multirow{3}{*}{$\begin{array}{l}\text { Soil water } \\
\text { tension (KPa) }\end{array}$} & \multicolumn{6}{|c|}{ HFM (g/plant) } \\
\hline & \multicolumn{3}{|c|}{2015} & \multicolumn{3}{|c|}{2016} \\
\hline & Cv. Eikoo & Cv. Kinjitsu & Mean & Cv. Eikoo & Cv. Kinjitsu & Mean \\
\hline $13-17$ & 463.0 & 591.3 & $527.2 \mathrm{a}^{*}$ & $1272.5 \mathrm{Aa}$ & $517.3 \mathrm{Ba}$ & 894.9 \\
\hline $23-27$ & 441.5 & 458.0 & $449.8 \mathrm{~b}$ & $1156.3 \mathrm{Aa}$ & $592.8 \mathrm{Ba}$ & 874.6 \\
\hline $33-37$ & 463.5 & 428.8 & $446.1 \mathrm{~b}$ & $892.0 \mathrm{Ab}$ & $595.6 \mathrm{Ba}$ & 743.8 \\
\hline $43-47$ & 438.0 & 440.0 & $439.0 \mathrm{~b}$ & $800.0 \mathrm{Ab}$ & $562.0 \mathrm{Ba}$ & 681.0 \\
\hline Mean & 471.6 & $479.5^{\mathrm{ns}}$ & - & 1030.2 & 567.0 & - \\
\hline \multirow[t]{2}{*}{ CV (\%) } & \multicolumn{2}{|c|}{10.9} & - & \multicolumn{2}{|c|}{16.0} & - \\
\hline & \multicolumn{6}{|c|}{ Productivity $\left(\mathrm{t} \mathrm{ha}^{-1}\right)$} \\
\hline $13-17$ & 25.7 & 32.8 & $29.3 \mathrm{a}^{*}$ & 70.7Aa & $28.7 \mathrm{Ba}$ & 49.7 \\
\hline $23-27$ & 24.5 & 25.4 & $24.9 \mathrm{~b}$ & $64.2 \mathrm{Aa}$ & $32.9 \mathrm{Ba}$ & 48.6 \\
\hline $33-37$ & 25.8 & 23.8 & $24.8 \mathrm{~b}$ & $49.6 \mathrm{Ab}$ & $33.4 \mathrm{Ba}$ & 41.5 \\
\hline $43-47$ & 24.3 & 27.8 & $26.1 \mathrm{~b}$ & $44.2 \mathrm{Ab}$ & $25.6 \mathrm{Ba}$ & 34.9 \\
\hline Mean & 25.1 & $27.5^{\mathrm{ns}}$ & - & 57.2 & 30.2 & - \\
\hline CV (\%) & \multicolumn{2}{|c|}{10.9} & - & \multicolumn{2}{|c|}{16.04} & - \\
\hline
\end{tabular}

${ }^{\text {ns }}$ not significant by Scott-Knott test $(\mathrm{p}>0,05)$. Means followed by same capital letters in the row and lowercase in the column do not differ statistically by Scott-Knott test $(\mathrm{p}>0,05)$. 
In a study by Seabra et al. (2014), evaluating the performance of seven Chinese cabbage cultivars in CáceresMT, under tropical climate, with average temperatures of $27.1^{\circ} \mathrm{C}$, the authors obtained head fresh mass ranging from 584 to $926.3 \mathrm{~g} /$ plant, 'Kinjitsu' presenting $883.3 \mathrm{~g} / \mathrm{plant}$, higher than that obtained in our two researches, 479.5 and $567.0 \mathrm{~g} /$ plant, respectively. On the other hand, head fresh mass obtained by these authors with 'Eikoo' (800.5 $\mathrm{g} /$ plant) was lower than that obtained in this study (1030 g/plant). Increased productivity $\left(60.9 \mathrm{t} \mathrm{ha}^{-1}\right)$ achieved by

Table 2. Head dry mass (HDM) and root dry mass (RDM) of Chinese cabbage plants submitted to different ranges of soil water stress in two researches. Dois Vizinhos, UTFPR, 2016.

\begin{tabular}{|c|c|c|c|c|c|c|}
\hline \multirow{3}{*}{$\begin{array}{l}\text { Soil water } \\
\text { tension } \\
\text { (KPa) } \\
\end{array}$} & \multicolumn{6}{|c|}{ HDM (g/plant) } \\
\hline & \multicolumn{3}{|c|}{2015} & \multicolumn{3}{|c|}{2016} \\
\hline & $\begin{array}{c}\text { Cv. } \\
\text { Eikoo }\end{array}$ & $\begin{array}{c}\text { Cv. } \\
\text { Kinjitsu }\end{array}$ & Mean & $\begin{array}{c}\text { Cv. } \\
\text { Eikoo }\end{array}$ & $\begin{array}{c}\text { Cv. } \\
\text { Kinjitsu }\end{array}$ & Mean \\
\hline $13-17$ & 30.0 & 30.0 & $30.0^{\text {ns }}$ & $87.3 \mathrm{Aa}^{*}$ & $39.3 \mathrm{Ba}$ & 63.3 \\
\hline $23-27$ & 27.5 & 33.0 & 30.3 & $91.5 \mathrm{Aa}$ & $40.5 \mathrm{Ba}$ & 66.0 \\
\hline $33-37$ & 28.0 & 27.5 & 27.7 & $38.8 \mathrm{Ab}$ & $36.8 \mathrm{Aa}$ & 37.8 \\
\hline $43-47$ & 30.0 & 31.0 & 30.5 & $31.4 \mathrm{Ab}$ & $41.5 \mathrm{Aa}$ & 36.5 \\
\hline Mean & 28.9 & $30.4^{\mathrm{ns}}$ & - & 62.3 & 39.5 & - \\
\hline \multirow[t]{2}{*}{ CV (\%) } & \multicolumn{2}{|c|}{17.0} & - & \multicolumn{2}{|c|}{23.9} & - \\
\hline & \multicolumn{6}{|c|}{ RDM (g/plant) } \\
\hline $13-17$ & 17.0 & 13.0 & $15^{\mathrm{ns}}$ & $25.0 \mathrm{Ab}$ & $20.3 \mathrm{Ba}$ & 22.7 \\
\hline $23-27$ & 17.0 & 15.0 & 16.0 & $28.3 \mathrm{Ab}$ & $20.8 \mathrm{Ba}$ & 24.6 \\
\hline $33-37$ & 15.0 & 13.1 & 14.0 & $38.0 \mathrm{Aa}$ & $19.5 \mathrm{Ba}$ & 28.8 \\
\hline $43-47$ & 14.0 & 13.0 & 13.6 & $40.0 \mathrm{Aa}$ & $21.0 \mathrm{Ba}$ & 30.5 \\
\hline Mean & 15.8 & $13.6^{\mathrm{ns}}$ & - & 32.8 & 20.4 & - \\
\hline $\mathrm{CV}(\%)$ & \multicolumn{2}{|c|}{17.9} & - & \multicolumn{2}{|c|}{24.1} & - \\
\hline
\end{tabular}

${ }^{n s}$ not significant by Scott-Knott test $(\mathrm{p}>0.05) ;{ }^{*}$ Means followed by same capital letters in rows and lowercase in columns do not differ statistically by Scott-Knott test ( $>0.05$ ).

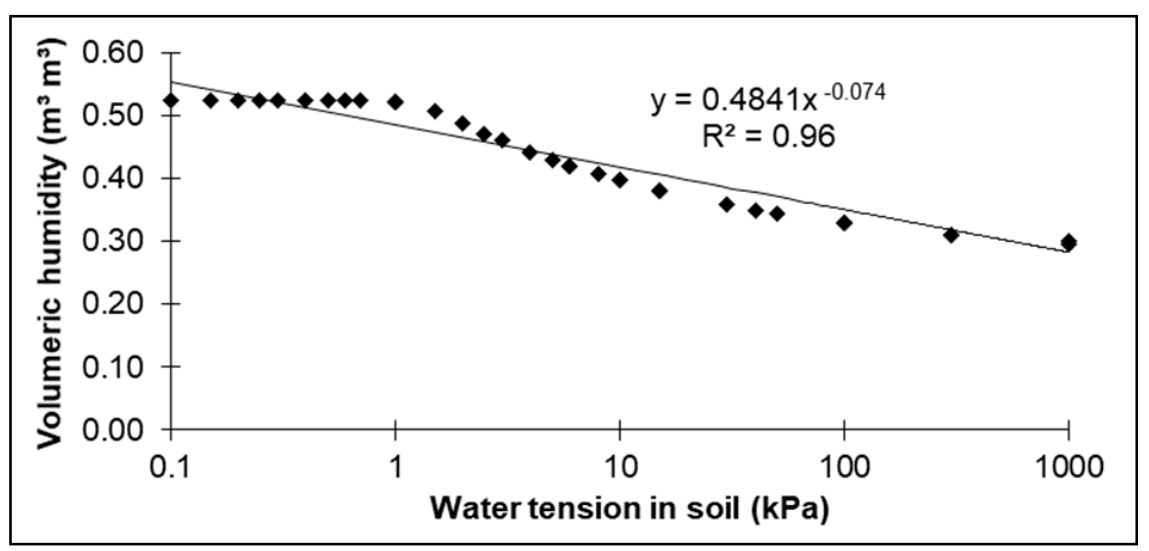

Figure 1. Soil water retention curve $0.10 \mathrm{~m}$ depth. Dois Vizinhos, UTFPR, 2016. other hand, 'Eikoo' presented fresh mass in the upper head in the stress ranges of 13-17 and 23-27 $\mathrm{kPa}$, with 1272.5 and $1156.3 \mathrm{~g} /$ plant, respectively, differing from the 33-37 and 43-47 $\mathrm{kPa}$ ranges, with 892 and $800 \mathrm{~g} /$ plant, respectively (Table 1).

Soil water stress ranges are related to the additional energy expenditure that the plant makes to absorb water and use it in its vital processes, when water availability is reduced by the potential matrix reduction (Floss, 2011). Thus, the energy of the photoassimilates resulting from the photosynthesis process may have been primarily intended for water absorption, to the detriment of crop growth.

For Brassicaceae species, such as broccoli and cauliflower, stresses between 10 and $12 \mathrm{kPa}$ are suggested (Thompson et al., 2002). Likewise, Marouelli (2008) indicated, for leafy vegetables in general, to keep the stress between $10-20 \mathrm{kPa}$, seeking the lower value for critical moments of development, where there is a greater water demand, such as the transplantation period and head forming. This way, Tangune et al. (2016) found that to obtain a larger and commercial fresh mass, inflorescence average diameter, total and commercial productivity for broccoli, irrigations should be performed when water stress in the soil is around $15 \mathrm{kPa}$, at 0.2 $\mathrm{m}$ depth. Higher stresses affect in a negative way productivity, fresh mass, diameter and circumference of the inflorescence.

In the first research, the cultivars Eikoo and Kinjitsu and the soil water stress ranges did not influence head dry mass (Table 2). In the second one, head dry masses and the 'Kinjitsu' root were not influenced by stress ranges (Table 2). Cultivar Eikoo had upper head dry mass under smaller stress ranges 13-17 and 23-27, which did not differ from each other. The stress ranges 33-37 and 43-47 differed from the first two 38.8 and $31.4 \mathrm{~g} /$ plant, respectively, but did not differ from each other.

In the first research, cultivars Eikoo and Kinjitsu and the soil water stress ranges did not influence the dry mass of roots (Table 2). This response was not 
observed in the second research, where a significant interaction was found and 'Eikoo' had lower root dry mass in lower stress ranges, 13-17 and 23-27 (25 and $28.3 \mathrm{~g} /$ plant, respectively). In addition, stress ranges 33-37 and 43-47 differed from the first two with 38.0 and $40.0 \mathrm{~g} /$ plant, respectively. This result pointed out a higher root growth in stress with less water availability and longer time

interval between irrigations. The lower availability of water intensified root growth in depth, therefore accumulating higher dry mass. Thus, the energy expenditure required for root growth was not available for the dry mass head accumulation, which may have contributed to the aerial dry mass reduction in these stress ranges.

One of the main reasons that Chinese

Table 3. Chinese cabbage plants heads circumference and compactness submitted to different ranges of soil water stress in two researches. Dois Vizinhos. UTFPR. 2016.

\begin{tabular}{|c|c|c|c|c|c|c|}
\hline \multirow{3}{*}{$\begin{array}{l}\text { Soil water } \\
\text { tension (KPa) }\end{array}$} & \multicolumn{6}{|c|}{ Heads circumference $(\mathrm{cm})$} \\
\hline & \multicolumn{3}{|c|}{2015} & \multicolumn{3}{|c|}{2016} \\
\hline & $\begin{array}{c}\text { Cv. } \\
\text { Eikoo }\end{array}$ & $\begin{array}{c}\text { Cv. } \\
\text { Kinjitsu }\end{array}$ & Mean & $\begin{array}{c}\text { Cv. } \\
\text { Eikoo }\end{array}$ & $\begin{array}{c}\text { Cv. } \\
\text { Kinjitsu }\end{array}$ & Mean \\
\hline $13-17$ & 38.8 & 36.4 & $37.6^{\mathrm{ns}}$ & 31.8 & 36.5 & $34.2^{\text {ns }}$ \\
\hline $23-27$ & 38.6 & 37.8 & 38.2 & 35.3 & 34.0 & 34.6 \\
\hline $33-37$ & 38.5 & 32.5 & 35.5 & 37.8 & 30.3 & 34.0 \\
\hline $43-47$ & 37.6 & 38.0 & 37.8 & 38.3 & 33.3 & 35.8 \\
\hline Mean & 38.4 & $36.2^{\text {ns }}$ & - & $35.8 \mathrm{~A}^{*}$ & $31.0 \mathrm{~B}$ & - \\
\hline \multirow[t]{2}{*}{$\mathrm{CV}(\%)$} & \multicolumn{2}{|c|}{8.9} & - & \multicolumn{2}{|c|}{10.6} & - \\
\hline & \multicolumn{6}{|c|}{ Compactness } \\
\hline $13-17$ & 3.0 & 3.5 & $3.3^{\mathrm{ns}}$ & 1.8 & 1.8 & $1.8^{\mathrm{ns}}$ \\
\hline $23-27$ & 2.5 & 3.3 & 2.9 & 1.3 & 2.3 & 1.8 \\
\hline $33-37$ & 2.8 & 2.5 & 2.6 & 1.8 & 2.5 & 2.1 \\
\hline $43-47$ & 2.8 & 2.8 & 2.8 & 2.5 & 2.3 & 2.4 \\
\hline Mean & 2.8 & $3.0^{\mathrm{ns}}$ & - & 1.8 & $2.2^{\mathrm{ns}}$ & - \\
\hline $\mathrm{CV}(\%)$ & \multicolumn{2}{|c|}{24.6} & - & \multicolumn{2}{|c|}{36.1} & - \\
\hline \multicolumn{7}{|c|}{$\begin{array}{l}\text { *Compactness notes ranging from } 0 \text { to } 5(0=\text { total head absence; } 1=\text { head without a defined } \\
\text { core; } 2=\text { outside core head and loose peripheral leaves; } 3=\text { defined core head and leaves with } \\
\text { inceptive compaction in the periphery; } 4=\text { defined core head and compact peripheral leaves } \\
\text { but with allowed visual individualization; } 5 \text { - head with compact core and without visual } \\
\left.\text { individualization of the peripheral leaves. }{ }^{\text {ns }} \text { not significant by Scott-Knott test ( }>0.05\right) \text {; } \\
\text { * Means followed by same capital letters in the row and lowercase in the column do not } \\
\text { differ statistically by Scott-Knott test }(p>0.05) \text {. }\end{array}$} \\
\hline
\end{tabular}

Table 4. Efficiency in water use of Chinese cabbage plants submitted to different ranges of soil water stress. Dois Vizinhos. UTFPR. 2016.

\begin{tabular}{lccccccc}
\hline $\begin{array}{l}\text { Soil water } \\
\text { tension (KPa) }\end{array}$ & \multicolumn{5}{c}{ Efficiency in water use $\left(\mathbf{k g ~ H D M} / \mathbf{m}^{\mathbf{3}}\right.$ of water) } \\
\cline { 2 - 5 } \cline { 1 - 4 } & $\begin{array}{c}\text { Cv. } \\
\text { Eikoo }\end{array}$ & $\begin{array}{c}\text { Cv. } \\
\text { Kinjitsu }\end{array}$ & Mean & & $\begin{array}{c}\text { Cv. } \\
\text { Eikoo }\end{array}$ & $\begin{array}{c}\text { Cv. } \\
\text { Kinjitsu }\end{array}$ & Mean \\
\hline $13-17$ & 32.7 & 42.1 & $37.4 \mathrm{a}^{*}$ & & 47.3 & 23.2 & $35.3 \mathrm{a}$ \\
$23-27$ & 17.6 & 18.3 & $18.0 \mathrm{~b}$ & & 32.2 & 16.5 & $24.4 \mathrm{~b}$ \\
$33-37$ & 12.6 & 13.8 & $13.2 \mathrm{c}$ & & 21.1 & 16.3 & $18.7 \mathrm{~b}$ \\
$43-47$ & 10.5 & 14.4 & $12.4 \mathrm{c}$ & & 14.2 & 10.1 & $12.2 \mathrm{c}$ \\
\hline Mean & $18.4 \mathrm{~B}$ & $22.2 \mathrm{~A}$ & - & & $28.7 \mathrm{~A}$ & $16.5 \mathrm{~B}$ & \\
CV (\%) & \multicolumn{2}{c}{11.1} & - & & 22.1 & - \\
\hline
\end{tabular}

*Means followed by same capital letters in the row and lowercase in the column do not differ statistically by Scott-Knott test ( $\mathrm{p}>0.05)$. cabbage and other leafy vegetables demand constant irrigation to achieve optimum production is because leaf production is linked to leaf expansion, which is the water stress most sensitive physiological process. The sensitivity of Chinese cabbage leaf production to water stress is probably more intense due to its superficial root system, that is, more than $90 \%$ of the roots occur up to $35 \mathrm{~cm}$ deep in the soil and 20 $\mathrm{cm}$ wide around the stem (Averbeke \& Netshithuthuni, 2010).

The soil water stress ranges did not influence 'Kinjitsu' roots growth, obtaining $20.4 \mathrm{~g} /$ plant, a lower value than that obtained with 'Eikoo' (32.8 g/plant) (Table 2). The absence of a significant difference in dry mass of roots is possibly related to the accumulation of similar dry mass of the head in 'Kinjitsu stress ranges, with no intense root development to meet the demand of aerial parts, as occurred in 'Eikoo'. This lower development may also be related to the 'Kinjitsu' low adaptation to summer-fall period climatic conditions. The soil water stress ranges did not influence head circumference and compactness (Table 3). Head circumference varied among cultivars, with 'Eikoo' superior to 'Kinjitsu'. This response is attributed to an increased head fresh mass obtained from 'Eikoo', being an intrinsic feature of the cultivar. Maseko et al. (2017) found that the Chinese cabbage fresh head production is related to environmental conditions (temperature), cultivar and planting density.

The compactness is highly appreciated by consumers and it is considered as an indication of a proper head formation. Values found in this study ranged between 2.5 and 3.5 in the first crop and 1.3 and 2.5 in the second one. In this way, there was a better head formation in the first culture, considering that values closer to five indicate better head quality (Seabra et al., 2014).

Studying seven Chinese cabbage cultivars, Seabra et al. (2014) found compactness ranging from 1.0 to 4.3 , and 'Kinjitsu' presented 2.9. This value is lower than that obtained in the first research (3.0), but higher than the 
one obtained in the second research (2.2) for 'Kinjitsu'. Considering that consumers prefer vegetables with good head formation, compactness is one of the most relevant features, which favors whitish leaves prevalence. For farmers, this is a feature that reduces transport volume and increases weight per plant.

In terms of numbers, compactness was lower in the second research, which could be associated with the early harvesting. There was an intense occurrence of erwinia (Erwinia carotovora) at the end of the cycle, mainly in 'Kinjitsu', which required early harvesting.

For water use efficiency, cultivars responded differently. In the first research, 'Kinjitsu' was more efficient $\left(22.2 \mathrm{~kg} \mathrm{~m}^{-3}\right)$, compared to 'Eikoo', which showed higher efficiency (28.7 $\mathrm{kg} \mathrm{m}^{-3}$ ) in the second research (Table 4). 'Eikoo's higher efficiency during the second research (summer) is the result of its higher productive capacity under higher temperature conditions in that period.

The soil water stress ranges influenced the water use efficiency in both researches (Table 4). The highest were $42.1 \mathrm{~kg} \mathrm{~m}^{-3}$ in the first research and $47.3 \mathrm{~kg} \mathrm{~m}^{-3}$ in the second, for Kinjitsu and Eikoo, respectively, in the stress range $13-17 \mathrm{kPa}$. Water use efficiency decreased with increasing soil water stress ranges. In plantings with lower water availability, water consumption was higher in both researches and the productivity was not increased, resulting in lower hydric efficiency. Likewise, in broccoli crop, the use of different soil water stresses $(15,30,45,60,75$ and $90 \mathrm{kPa}$ ) did not result in water use efficiency change (Tangune et al., 2016).

Averbeke \& Netshithuthuni (2010) found in studies with different irrigation scheduling practices that Chinese cabbage is not efficient in water use, and in two-thirds of its growth period, the first six to seven weeks, water use was mostly destined for soil surface evaporation due to the small size and smaller leaf area of the plants. High frequency irrigation scheduling did not result in high production but led to a considerable amount of water drained to the rooting zone. The authors suggest that irrigation methods, that allow better control over the amount of water applied per irrigation event, would make water use more efficient.

In summertime, cultivar Eikoo was more productive and in the fallwinter period, the two cultivars, Eikoo and Kinjitsu, can be cultivated in protected environment due to favorable environmental conditions. The stress range between 13-17 $\mathrm{kPa}$ allowed higher productivity and efficiency in water use.

\section{ACKNOWLEDGEMENTS}

The authors thank the Conselho Nacional de Desenvolvimento Científico e Tecnológico (CNPQ) for scientific initiation grant and the financial support to conduct the study.

\section{REFERENCES}

ALLEN, RG; PEREIRA, LS; RAES, D; SMITH, M. 1998. Crop evapotranspiration-guidelines for computing crop water requirements. Irrigation and Drainage Paper 56. 300p.

ALVARES, CA; STAPE, JL; SENTELHAS, PC; GONÇALVES, JLM; SPAROVEK, G. 2013. Köppen's climate classification map for Brazil. Meteorologische Zeitschrift. 22: 711-728.

AVERBEKE, WV; NETSHITHUTHUNI, C. 2010. Effect of irrigation scheduling on leaf yield of non-heading Chinese cabbage (Brassica rapa L. subsp. chinensis), South African Journal of Plant and Soil 27: 322-327.

BERNARDO, S; SOARES, AA; MANTOVANI, EC. 2006. Manual de Irrigação. Viçosa: UFV. 625p.

BESHIR, S. 2017. Review on estimation of crop water requirement, irrigation frequency and water use efficiency of cabbage production. Journal of Geoscience and Environment Protection 5: 59-69.

BRASIL, AG. 2010. Catálogo Brasileiro de Hortaliças. Brasília: Embrapa Hortaliças \& Sebrae. 60p.

CRUZ, CD. 2006. Programa Genes: Biometria. Viçosa: UFV. 382p.

DOORENBOS, J; KASSAM, AH. 1994. Efeito da água no rendimento das culturas. Campina Grande: UFPB. 306p.

EMBRAPA - Empresa Brasileira de Pesquisa Agropecuária. 2018. Sistema brasileiro de classificação de solos. 5.ed. Rio de Janeiro: Embrapa.

FLOSS, EL. 2011. Fisiologia das plantas cultivadas. Passo Fundo: UPF. 734p.

HORTICERES. 2015. Couve chinesa hib. 'Eikoo': resultados de campos continuam excelentes.
Available http://www.horticeres.com.br/ noticeres/couve-chinesa-hib-'Eikoo' Accessed April 25, 2015.

LACZI, E; APAHIDEAN, A; LUCA, E; DUMITRAS, A; BOANCĂ, P. 2016. Headed Chinese cabbage growth and yield influenced by different manure types in organic farming system. Horticultural Science 43: 42-49.

MANTOVANI, EC; BERNARDO, S; PALARETTI, LF. 2009. Irrigação: princípios e métodos. 3. ed. Viçosa: UFV. 355p.

MAROUELLI, WA. 2008. Tensiometros para controle de irrigação em hortaliças. Brasília: Embrapa. 15p.

MASEKO, I; BELETSE, YG; NOGEMANE, $\mathrm{N}$; PLOOY, CP; MUSIMWA, TR; MABHAUDHI, T. 2017. Productivity of non-heading Chinese cabbage (Brassica rapa subsp. chinensis) under different agronomic management factors. South African Journal of Plant and Soil 34: 275-282.

MICHELON, CJ; CARLESSO, R; OLIVERIRA, ZB; KNIES, AE; PETRY, MT; MARTINS, JD. 2010. Funções de pedotransferência para estimativa da retenção de água em alguns solos do Rio Grande do Sul. Ciência Rural 40: 848-853.

MUALEM, YA. 1976. A new model for predicting the hydraulic conductivity of unsaturated porous media. Water Resource Research 12: 513-522.

SEABRA, SJ; PEREIRA, AS; ARAUJO, KL. 2014. Desempenho de cultivares de couve chinesa em Cáceres-MT. Horticultura Brasileira 32: 504-507.

SEGOVIA, JFO; MELEM JUNIOR, NJ; AZEVEDO DIAS, JS; LOPES FILHO, RP. 2000. O cultivo de couve chinesa no Amapá. Macapá: Embrapa. 20p.

SOUZA, AL; JUNIOR, SS; DIAMANTE, MS; SOUZA, LH; NUNES, MCM. 2013. Comportamento de cultivares de alface americana sob clima tropical. Revista Caatinga 26: $123-129$

TANGUNE, FB; PEREIRA, GM; SOUSA, RJ; GATTO, RF. 2016. Produção de brócolis irrigado por gotejamento, sob diferentes tensões de água no solo. Semina: Ciências Agrárias 37: 7-16.

THOMPSON, TL; DOERGE, TA; GODIN, RE. 2002. Subsurface drip irrigation and fertigation of broccoli. Soil Science Society of America Journal 66: 186-192.

TOPSEED. Sementes couve chinesa hibrida 'Kinjitsu' R F1. 2015. Available http://agristar. com.br/topseed-premium/couve-chinesahibrida/'Kinjitsu' -r-f1/337 Accessed April 25, 2015.

VAN GUENUCHEN, MT. 1980. A closed form equation for predicting the hydraulic conductivity of unsaturated soils. Soil Science Society of America Journal 44: 892-898.

VAN GENUTCHTEN, MT; LEIJ, FJ; YATES, SS. 1991. The RETC code for quantifying the hydraulic function of unsaturated soils: version 6.02 V.S. Riverside: USDA, Salinity Laboratory. Available $<\mathrm{http} / / / \mathrm{www}$. pc-progress.com/en/Default.aspx?retcdownloads $>$. Accessed April 20, 2015. 